\title{
Analisis SWOT Untuk Strategi Pengembangan Home Industry Kue Gapit Sampurna Jaya Kabupaten Cirebon
}

\author{
Syaeful Bakhri' ${ }^{1}$, Abdul Aziz ${ }^{2}$, Ummi Khulsum ${ }^{3}$ \\ IAIN Syekh Nurjati Cirebon \\ ${ }^{1}$ e-mail: sultan01aulia@yahoo.com \\ 2 e-mail: razi_ratnaaziz@yahoo.co.id \\ 3 e-mail: ummikhulsum01@gmail.com
}

\begin{abstract}
ABSTRAK
Tujuan dari kegiatan pengabdian ini adalah sebagai upaya untuk meningkatkan kualitas manajemen Home Industry Kue Gapit Sampurna Jaya melalui penyusunan strategi usaha yang tepat dan akurat agar dapat mengembangkan home industry tersebut yang mana saat ini sudah mulai dikenal masyarakat banyak karena cita rasa makanannya sangat khas. Alat analisis yang digunakan adalah melalui Analisis SWOT untuk membantu mengidentifikasi berbagai faktor yang terbentuk secara sistematis yang digunakan untuk merumuskan strategi perusahaan. Analisis SWOT dapat diterapakan dengan cara menganalisis dan memilih hal-hal yang memengaruhi keempat faktornya. Penelitian ini merupakan penelitian lapangan dengan metode kualitatif bersifat deskriptif. Dari hasil penelitian, strategi produsen agar dapat terus bersaing yaitu menjaga kualitas produk dengan bahan baku yang berkualitas baik, memberi pelayanan yang baik, harga bersaing dan pemasaran online. Sedangkan analisis SWOT diantaranya memaksimalkan produksi, menjaga kualitas produk, menyediakan lahan parkir, menambah variasi rasa gapit, menambah modal serta memperluas pemasaran.
\end{abstract}

Kata kunci: Analisis SWOT, Strategi Pengembangan, Home Industry

\begin{abstract}
The aim of this community service activity is as an effort to improve the quality of home industry management of Gapit Sampurna Jaya Cake through the preparation of appropriate and accurate business strategies to develop the home industry which is now beginning to be known to the public because of its very distinctive food taste. The analytical tool used is through SWOT Analysis to help identify various systematically formed factors that are used to formulate a company's strategy. SWOT can be applied by analyzing and choosing things that affect the four elements. This research is field research with a descriptive qualitative method. From the results of the research, the producers' strategy is to continue to compete, namely maintaining product quality with good quality raw materials, providing good service, competitive prices, and online marketing while the SWOT analysis includes maximizing production, maintaining product quality, providing parking space, adding variety to a sense of nimble, increasing capital and expanding marketing.
\end{abstract}

Keywords: SWOT Analysis; Development Strategy; Home Industry 


\section{PENDAHULUAN}

Secara universal dan global, kompetisi bisnis akan diwarnai dengan perubahan kompleks dari berbagai kombinasi faktor politik, ekonomi, teknologi, sosial dan budaya, disamping pengaruh dari pelaku bisnis yang bersangkutan. Dalam hal tersebut, pelaku bisnis (usaha kecil) akan tersudut dalam memposisikan dirinya secara baik dan benar dibandingkan pesaingnya untuk memperebutkan konsumen, bila tidak disadari secara cepat atau lambat melalui berbagai upaya (Hubeis, 2009).

Upaya yang dapat dilakukan salah satunya adalah dengan melakukan analisis SWOT, analisis ini dapat dijadikan sebagai landasan pelaku usaha agar dapat mencapai target usahanya. Jika alat analisis ini digunakan dengan tepat, maka hal tersebut dapat berbanding lurus dengan keakuratan perumusan strategi dalam usaha untuk mencapai tujuanny, yang kemudian dapat meminimalisir resiko dalam menghadapi ancaman, serta memanfaatkan dan mengejar peluang yang ada (Nuraini, 2019). Kegunaan analisis SWOT ini cukup simple namun ternyata dapat membantu penyusunan strategi baik organisasi maupun perusahaan. Secara umum, analisis SWOT memiliki kegunaan sebagai berikut : digunakan untuk menganalisis kondisi diri dan lingkungan pribadi, digunakan untuk menganalisis kondisi internal lembaga dan lingkungan eksternal lembaga, digunakan untuk mengetahui sejauh mana diri kita di dalam lingkungan kita, digunakan untuk mengetahui posisi sebuah perusahaan/organisasi diantara perusahaan/organisasi yang lain serta digunakan untuk mengetahui kemampuan sebuah perusahaan dalam menjalankan bisnisnya dihadapkan dengan para pesaingnya (Nuraini, 2019).

Kue Gapit merupakan salah satu camilan atau makanan ringan kering (kue kering) di Indonesia yang berasal dari Cirebon, Jawa Barat dan sampai kini masih popular dikalangan masyarakat. Penamaan kue "gapit" diambil dari proses pembuatannya/pencetakannya yang terbuat dari tepung tapioka. Makanan ringan tersebut memiliki berbagai bentuk dan rasa yang khas dengan tekstur yang kering, renyah, dan tahan lama. Perkembangan kue gapit yang ada dipasaran mengalami kemajuan yang cukup baik. Umumnya kue gapit dipasarkan dengan kemasan plastik yang dikemas dalam berbagai macam ukuran dan berat. Makanan ringan kering tersebut telah lama kini menjadi salah satu ciri khas suatu daerah di Kabupaten Cirebon, yaitu Desa Panembahan. Sebenarnya terdapat banyak olahan makanan ringan/ kue yang diproduksi di daerah tersebut, namun sebagian besar masyarakat Desa Panembahan lebih banyak menjalankan usahanya untuk memproduksi makanan ringan kering Gapit tersebut.

Penelitian terkait strategi pengembangan Home Industry sudah banyak dilakukan oleh beberapa peneliti sebelumnya, (Zuhri, 2013) menjelaskan bahwa strategi pengembangan Home 
Industry dapat dilakukan melalui diadakannya kegiatan pelatihan dan pembinaan khusus untuk pengembangan pengelolaan usaha kecil pada tenaga kerja, memaksimalkan jumlah produksi (Sulistiowati, Aji, \& Hartadi, 2017) melalui pemanfaatan kecanggihan teknologi dengan sistm manajemen yang mengikuti perkembangan teknologi modern tersebut(Mas, Yantu, \& Howara, 2013). Melakukan perluasan pemasaran dengan cara kegiatan promosi yang intensif dan efisien ke daerah-daerah yang belum terjangkau sebelumnya, melakukan pemasaran yang mengikuti era perkembangan zaman seperti media online, titip jual, endors dan bazar (Fazizah, 2015). Dapat pula melalui jalinan kerjasama yang baik dengan pemerintah (Irmawati, 2015) maupun subsistem hulu dan hilir untuk kemudian dapat membantu dalam pengadaan kegiatan pelatihan tersebut diatas.

Selain itu (Fitrio, 2016) menambahkan terkait strategi peningkatan pelayanan konsumen dapat dilakukan dengan membuka layanan pelanggan melalui e-mail maupun SMS (Short Message Service) untuk menerima maupun menindaklanjuti setiap keluhan-keluhan yang disampaikan oleh pelanggan. Hal tersebut tentunya akan berpengaruh pada peningkatan kinerja perusahaan yang dalam hal ini adalah home industry itu sendiri. Namun diluar itu semua, terdapat satu diantara strategi lainnya yang dianggap sangat penting untuk pengembangan home industry menurut (Juliandini, Syahza, \& Indrawati, 2017) adalah dengan tetap mempertahankan kualitas produk, mulai dari ciri khas, cita rasa produk sehingga kepercayaan pelanggan tetap terjaga dengan baik dan tentunya agar dapat bersaing dengan produk sejenis maupun produk lainnya. Berdasarkan pemaparan latar belakang diatas, maka penulis tertarik untuk membahas mengenai Analisis SWOT sebagai Strategi pengembangan Home Industry Kue Gapit Sampurna Jaya Kabupaten Cirebon.

\section{BAHAN DAN METODE}

Home industry merupakan usaha yang tergolong dalam skala kecil. Usaha kecil adalah industri yang menyerap tenaga kerja 1-9 orang 9 tenaga kerja. Lambing menjelaskan bahwa kontrol atau pengawasan usaha kecil biasanya bersifat informal. Apabila hanya terdapat beberapa karyawan, deskripsi pekerjaan dan segala aturan lebih baik secara tidak tertulis sebab wirausahawan mudah mengontrol usahanya (Suryana, 2013). Sementara menurut (Muliawan, 2008), Home industry adalah suatu unit usaha/perusahaan dalam skala kecil yang bergerak dalam bidang industri tertentu. Usaha ini tentunya hanya menggunakan satu atau dua rumah sebagai pusat produksi, admisistrasi dan pemasaran sekaligus. Jika dilihat dari modal usaha dan jumlah tenaga kerja yang diserap biasanya lebih sedikit daripada perusahaan-perusahaan besar pada 
umumnya Home industry Kue Gapit Sampurna Jaya di Desa Panembahan tergolong pada Home industry karena usaha tersebut sesuai dengan karakteristik dari home industry atau industri rumah tangga. Selain itu dalam kegiatan proses produksinya juga masih menggunakan alat tradisioanal dan manual.

Strategi merupakan sebuah alat untuk mencapai tujuan. Konsep strategi berkaitan erat dengan sebuah perencanaan untuk mencapai arah tujuan jauh ke depan. Strategi adalah pola, sebab strategi itu masih berbentuk perencanaan yang berorientasi ke masa depan dan belum terlaksana. Tetapi jika sudah terlaksana, disebut dengan realized strategy. Strategi juga berarti posisi, yaitu strategi memposisikan produknya ke pasar pasaran. Ada dua model strategi jenis ini: (1) melihat kebawah, yaitu melihat titik temu antara produk dengan pelanggannya; (2) melihat keluar, yaitu memperhatikan berbagai aspek lingkungan eksternal yang mempengaruhi pasar. Strategi juga bisa berarti permainan atau taktik perusahaan dalam memperdaya pesaingnya, ibarat permainan sepakbola, diperlukan taktik ketika menggiring bola untuk mengecoh lawan sehingga dapat dengan mudah memasukkan bola ke gawang lawan. Jadi, strategi dimaknai bukan hanya sekedar membuat sesuatu menjadi lebih baik lagi, lebih dari itu strategi adalah menjadikan sesuatu menjadi lebih baru, baik dan berbeda (Yunus, 2008).

Berikut merupakan beberapa strategi yang dapat digunakan untuk memajukan dan mengembangkan suatu usaha agar dapat bertahan dalam jangka panjang dalam (Pearce, B, \& Robinson, 2013), yaitu:

\section{Strategi pengembangan pasar}

Suatu strategi utama untuk memasarkan sebuah produk yang ada kepada konsumen, sering kali terkait hanya dengan modifikasi tipis, dengan cara menambah saluran distribusi atau dengan cara menambah konten iklan atau promosi.

2. Strategi pengembangan produk

Dalam strategi pengembangan produk juga dibutuhkan modifikasi terhadap suatu produk yang ada saat ini atau penciptaan produk yang baru, namun masih terkait yang dapat dipasarkan pada pelanggan saat ini melalui saluran distribusi yang sudah ada. Dengan cara ini perusahaan dapat mampu bertahan, memperkuat posisi dan memperluas pangsa pasar dengan menghadirkan produk-produk baru yang dipasarkan.

3. Strategi inovasi

Strategi ini merupakan strategi untuk meraih keuntungan yang tinggi berkaitan dengan penciptaan atau penerimaan pelanggan atau produk baru atau yang telah diperbaiki. 
Oleh sebab itu, dapat dipahami bahwa dalam pengambilan keputusan suatu tindakan pengembangan diperlukan adanya strategi. Dengan demikian, strategi pengembangan yang tepat ialah dengan adanya analisis SWOT yang merupakan akronim dari Strength (kekuatan), Weakness (kelemahan), Opportunity (peluang), dan Threat (ancaman).

Analisis SWOT menurut (Suryatama, 2014) adalah sebuah metode perencanaan strategi yang digunakan untuk mengevaluasi kekuatan, kelemahan, peluang dan ancaman dalam suatu proyek atau suatu spekulasi bisnis. Proses ini melibatkan penentuan tujuan yang spesifik dari spekulasi bisnis atau proyek dan mengidentifikasikan faktor internal dan eksternal yang mendukung dan yang tidak dalam mencapai tujuan tersebut. Dalam mengidentifikasi suatu masalah yang timbul didalam perusahaan, maka diperlukan penelitian yang sangat cermat sehingga mampu menentukan strategi yang sangat cepat dan tepat untuk mengatasi masalah yang timbul dalam perusahaan tersebut. Berikut beberapa pertimbangan yang perlu diperhatikan dalam mengambil keputusan antara lain :

\section{Kekuatan (Strenght)}

Kekuatan adalah unsur-unsur yang dapat diunggulkan oleh perusahaan tersebut seperti halnya keunggulan dalam produk yang dapat diandalkan, memiliki keterampilan dan berbeda dengan produk lain. Sehingga dapat membuat lebih kuat dari pada pesaingnya. Kekuatan adalah sumber daya, keterampilan, atau keunggulan- keunggulan lain yang membedakan terhadap pesaing. Kekuatan adalah kopetensi khusus yang memberikan keunggulan bagi perusahaan di pasar. Kekuatan terdapat pada sumber daya, keuangan, citra, kepemimpinan pasar, hubungan pembeli-pemasok, dan faktor-faktor lain.

2. Kelemahan (weakness)

Kelemahan adalah kekuarangan atau keterbatasan dalam hal sumber daya yang ada pada perusahaan baik itu keterampilan atau kemampuan yang menjadi penghalang bagi kinerja organisasi. Keterbatasan atau kekuarangan dalam sumber daya, keterampilan dan kapasitas yang secara serius menghambat kinerja efektif perusahaan. Fasilitas, sumber daya keuangan, kapasitas manajemen, ketermpilan pemasaran, dan citra merek dapat merupakan sumber kelemahan.

3. Peluang (opportunity)

Peluang adalah berbagai hal dan situasi yang menguntungkan bagi suatu perusahaan.

4. Ancaman (Treatment)

Ancaman adalah faktor-faktor lingkungan yang tidak menguntungkan dalam perusahaan jika tidak diatasi maka akan menjadi hambatan bagi perusahaan yang bersangkutan baik 
masa sekarang maupun yang akan datang. Ancaman merupakan pengganggu utama bagi posisi perusahaan. Masuknya pesaing baru, lambatnya pertumbuhan pasar, meningkatkanya kekuatan tawar-menawar pembeli atau pemasok penting, perubahan teknologi, serta peraturan baru atau yang direvisi dapat menjadi ancaman bagi keberhasilan perusahaan

Adapun media yang dapat digunakan untuk menentukan strategi setelah ditemukan komponen-komponen analisis SWOT adalah Matrik SWOT. Matriks SWOT dapat menggambarkan secara jelas peluang dan ancaman eksternal yang dihadapi perusahaan dapat disesuaikan dengan kekuatan dan kelemahan yang dimiliki perusahaan. Matrik SWOT dipergunakan sebagai alat penyesuaian yang mengembangkan empat tipe alternatif strategis yaitu SO (memanfaatkan seluruh kekuatan untuk merebut dan memanfaatkan peluang yang sebesarbesarnya), WO (pemanfaatan peluang yang ada dengan cara meminimalkan kelemahan yang ada), ST (menggunakan kekuatan yang dimiliki perusahaan untuk mengatasi ancaman), dan WT (meminimalkan kelemahan yang ada serta menghindari ancaman) (Rangkuti, 2008).

Jenis penelitian ini adalah penelitian lapangan yaitu penelitian dengan data yang diperoleh dari penelitian langsung pada kegiatan di lapangan kerja penelitian. Penelitian ini merupakan penelitian non doktrinal, yaitu menggunakan teori yang sudah ada kemudian dikembangkan lebih lanjut sesuai dengan kondisi di lapangan (Supriadi, 2005). Metode penelitian yang digunakan adalah metode penelitian kualitatif bersifat deskriptif. Penelitian kualitatif yaitu metode penelitian yang digunakan untuk meneliti pada kondisi objek alamiah. Teknik pengumpulan data dilakukan secara induktif yakni penarikan kesimpulan berdasarkan keadaan-keadaan yang khusus untuk diperlakukan secara umum(Riduwan, 2010). Sifat dari penelitian ini adalah deskriptif yaitu tipe penelitian untuk memberikan data yang seteliti mungkin tentang suatu gejala atau fenomena, agar dapat membantu dalam memperkuat teori-teori yang sudah ada, atau mencoba merumuskan teori baru. Data yang dikumpulkan berupa kata-kata, gambar dan bukan angka-angka. Hal itu disebabkan oleh adanya penerapan metode kualitatif (Suryabrata, 2004).

Sifat penelitian ini adalah penelitian kualitatif. Penelitian kualitatif adalah pendekatan penelitian yang digunakan untuk meneliti pada kondisi objek yang alamiah, bersiat deskripstif dan cenderung menggunakan analisis. Hasil penelitian kualitatif lebih menekankan makna dari pada generalisasi (Sugiyono, 2005). Data yang dikumpulkan penulis menggunakan observasi, 
wawancara, dokumentasi dan studi pustaka yang berkaitan dengan analisis SWOT yaitu yang berada di Home Industry Kue Gapit Sampurna Jaya.

Observasi yaitu merupakan teknik pengumpulan data yang dilakukan dengan cara pengamatan terhadap gejala-gejala yang diselidiki, wawancara yaitu dalam bentuknya yang paling sederhana wawancara terdiri atas sejumlah pertanyaan yang dipersiapkan oleh peneliti dan diajukan kepada seseorang mengenai topik penelitian secara tatap muka dan peneliti merekam jawaban- jawabannya sendiri (Emzir, 2012). Wawancara pada penelitian ini dilakukan dengan narasumber dari pemilik Home Industry Kue Gapit Sampurna Jaya Desa Panembahan, Karyawan Home Industry Kue Gapit Sampurna Jaya Desa Panembahan dan Konsumen serta masyarakat Home Industry Kue Gapit Sampurna Jaya Desa Panembahan, dokumentasi yaitu mencari data mengenai hal-hal atau variabel yang berupa catatan, transkip, buku, surat kabar, majalah, notulen, dan agenda dan studi pustaka adalah mengumpulkan informasi sebanyak-banyaknya dari kepustakaan yangberhubungan. Sumber-sumber kepustakaan dapat diperoleh dari buku, jurnal, majalah, hasil penelitian, dan sumber-sumber lainnya seperti Koran dan lainnya (Nazir, 2005).

\section{HASIL DAN PEMBAHASAN}

\section{Strategi Produsen Kue Gapit Sampurna Jaya untuk bersaing dipasaran}

Dalam menjalankan suatu bisnis, adanya persaingan pasar memang bukan hal yang baru. Seperti pengusaha makanan gapit di Desa Panembahan ini sudah banyak yang memproduksi gapit. Banyak cara yang dapat dilakukan untuk dilakukan agar usahanya tidak kalah saing dengan usaha lainnya, sehingga masih bisa bertahan bahakan berkembang lebih maju ditengah persaingan pasar yang semakin ramai. Produsen kue gapit Sampurna Jaya melakukan beberapa strategi agar usahanya tetap dapat berjalan maju, seperti;

1. Menjaga kualitas produk dengan menggunakan bahan baku yang berkualitas. Pada Home Industry Gapit Sampurna Jaya tentu memberikan rasa yang berbeda dari gapit lainnya. Testi rasa dari para pelanggan gapit pun sudah banyak, mereka ketagihan dengan rasa gapit di Home Industri ini karena mereka lebih mementingkan mendapatkan rasa yang enak dari pada harga yang murah tetapi mendapatkan kualitas yang biasa saja. Sedangkan dalam pemilihan bahan baku juga mereka menggunakan bahan baku yang berkualitas juga. Seperti dalam penggunaan keju, yang digunakan ialah keju craft, menggunakan kacang yang berkualitas baik. 
2. Memberikan pelayanan yang baik bagi pelanggan.

Pelayanan yang baik penting bagi kelancaran usaha. Pada Home Industry Kue Gapit Sampurna Jaya tentu memberikan pelayanan yang prima bagi pelanggannya supaya mereka merasa senang dan kerjasama bisnis menjadi terjalin dengan baik. Pelayanan prima maksudnya, apabila ada yang memesan gapit langsung diantarkan sesuai dengan permintaan waktu dan jumlah pesanan gapit.

3. Menawarkan harga bersaing.

Home Industry Gapit Sampurna Jaya menawarkan harga mulai dari kemasan kecil hingga besar. Harga yang mereka cantumkan sebenarnya lebih tinggi dari produsen gapit lainnya. Akan tetapi mereka berani menawarkan dengan harga tinggi karena produk yang mereka jual itu berkualitas baik. Harga gapit di Sampurna Jaya lebih tinggi yaitu Rp.40.000;/kilogram sedangkan di produsen gapit lain harga 1 kilogram hanya dibandrol Rp.25.000; - Rp.30.000.

4. Mencoba pemasaran online.

Teknologi sudah semakin canggih, begitu pula yang dimanfaatkan oleh produsen home industry gapit Sampurna Jaya. Mereka mulai beranjak ke sistem online untuk pemasaran gapitnya, walaupun masih sedikit pembeli gapit yang melalui sitem onlinenya. Home Industry ini sudah mencantumkan alamat di google maps.

\section{Analisis SWOT dalam pengembangan usaha Home Industry Kue Gapit Sampurna Jaya}

Dalam pengembangan home indsutry Kue Gapit Sampurna Jaya ini perlu memperhatikan dan menganalisis SWOT dalam proses pengambilan keputusan dan perencanaan strategis perusahaan. Karena perkembangan suatu usaha sangat berpengaruh oleh adanya faktor internal dan faktor eksternal yang terdapat dalam suatu home industry tersebut. Maka kedua faktor tesebut harus dipertimbangkan dalam analsis SWOT.

1. Strenght (Kekuatan).

Strength (kekuatan) adalah faktor-faktor internal suat perusahaan yang bersifat positif yang dapat berperan terhadap kemampuan perusahaan untuk mencapai tujuan pada suatu perusahaan. Strength merupakan kondisi yang menjadi sumber kekuatan dalam suatu perusahaan. Faktor ini merupakan nilai plus atau keunggulan dari suatu perusahaan tersebut.

Berikut yang menjadi kekuatan home industry Kue Gapit Sampurna Jaya diantaranya: Produk tahan lama dan berkualitas Produk dalam suatu usaha merupakan salah satu hal yang paling berpengaruh dalam suatu usaha. Kualitas produk yang di 
tawarkan dalam suatu usaha juga berpengaruh terhadap kekuatan dari suatu perusahaan tersebut. Home Industry Kue Gapit Sampurna Jaya memiliki kekuatan dari segi produk yang dihasilkan yaitu gapit yang memiliki rasa enak dan gurih serta tahan lama. Kekuatan produk gapit Sampurna Jaya sekitar 3 bulan bertahan, sedangkan dari segi ciri gapitnya berbeda dengan yang lain yaitu terlihat seperti terlihat lebih halus dan berisi.

a. Bahan baku yang mudah didapat

Bahan baku adalah salah satu komponen yang dijadikan dalam proses produksi pada suatu usaha. Bahan baku gapit masih tergolong mudah untuk didapatkan. Para pelaku usaha gapit tidak kesusahan untuk mencari bahan baku untuk membuat gapit tersebut. Ketersediaan bahan baku yang mudah didapatkan ini menjadikan para pelaku usaha tidak perlu khawatir akan kelangkaan yang membuat ketdaklancaran dalam produksinya. Bahan utama yang digunakan yaitu tepung tapioka. Kemudian bahan pelengkap seperti daun bawang, keju, kacang dan penyedap rasa. Bahan baku yang mereka gunakan biasanya membeli di pasar tradional seperti Pasar Pasalaran Plered dan Pasar Caplek Bode.

b. Tempat lokasi usaha yang strategis

Lokasi usaha merupakan hal yang terpenting dalam suatu usaha. Karena biasanya para konsumen akan langsung mengunjungi tempatnya untuk membeli hasil produk tersebut. Home Industry Kue Gapit Sampurna Jaya berada di Desa Panembahan blok Sampurna, yang lokasinya dekat dengan jalan raya tentunya akan mudah dikunjungi.

c. Cita rasa yang lebih khas

Cita rasa merupakan salah satu ciri khas pada hasil produksi. Apabila dalam suatu perusahaan memiliki cita rasa yang khas dapat membedakan dari perusahaan lainnya, maka hasil produksi sangat di minati para konsumennya. Home Industry Kue Gapit Sampurna Jaya memiliki cita rasa yang berbeda dari gapit lainnya. Mereka menggunakan resep yang rahasia untuk memuaskan para konsumennya.

d. Harga produk yang bersaing dalam mementingkan produk

Harga merupakan sebutan nilai suatu barang yang harus dibayarkan untuk mendapatkan suatu produk. Penetapan harga yang tepat akan memberikan keuntungan bagi penjual atau produsen. Home Industry Kue Gapit Sampurna Jaya memiliki harga yang dapat dijangkau oleh konsumen. Harga gapit Sampurna Jaya tergolong tinggi, tetapi mereka mementingkan kualitas yang bagus untuk menjaga produk mereka agar tetap baik. 
2. Weakness (Kelemahan)

Weakness adalah faktor-faktor internal perusahaan yang bersifat negatif yang ada dalam suatu perusahaan dan tentunya akan menghambat pencapaian tujuan yang ingin dicapai oleh perusahaan tersebut. Masalah yang dihadapi pada setiap perusahaan hendaknya diminimalisir karena jika faktor kelemahan lebih dominan maka perusahaan tidak akan mampu dalam bersaing. Pada dasarnya kelemahan merupakan suatu hal yang wajar ada dalam organisasi. Namun yang terpenting adalah bagaimana suatu perusahaan dapat memabangun sebuah kebijakan sehingga dapat meminimalkan kelemahan tersebut atau bahkan dapat menghilangkan kelemahan yang ada. Berikut yang menjadi kelemahan dalam Home Industry Kue Gapit Sampurna Jaya yaitu :

a. Tidak adanya pelatihan pada tenaga kerja

Pelatihan tenaga kerja hendaknya diadakan karena bagaimanapun juga tenaga kerja adalah salah satu hal yang dapat mempengaruhi proses produksi untuk menghasilkan produk yang berkualitas. Di Home Industry Kue Gapit Sampurna Jaya para tenaga kerjanya tidak diberikan pelatihan dalam membuat gapit. Saat mereka bekerja di home industry tersebut sudah mempunyai skill masing-masing.

b. Modal yang masih terbatas

Dalam produksi pasti membutuhkan modal untuk dapat menghasilkan barang. Home Industry Kue Gapit masih memiliki keterbatasan dalam hal modal. Mereka tidak meminjam modal ke lembaga manapun. Jika akan produksi gapit mereka menggunakan modal seadanya, dan jika permintaan konsumen ramai biasanya para konsumen tersebut memberikan uang DP (Down Payment) terlebih dahulu.

c. Tidak ada lahan parkir untuk konsumen

Home Industry Kue Gapit Sampurna Jaya tidak menyediakan lahan parkir khusus untuk pembelinya. Mereka menggunakan lahan untuk parkir seadanya yaitu di sekitar tempat usaha/rumahnya.

d. Variasi rasa kue gapit yang sedikit

Banyak variasi rasa merupakan hal yang bisa dijadikan alat untuk menarik para konsumen. Variasi rasa juga dalah salah satu trik untuk mengatasi agar para konsumen tidak bosan dengan hasil produk yang dipasarkan. Di home industry kue gapit Sampurna Jaya hanya memiliki tiga varian rasa yaitu bawang, keju dan kacang.

e. Kurangnya pemasaran dan promosi

Dalam memproduksi suatu barang tentunya banyak hal yang harus diperhatikan seperti jumlah barang yang diproduksi, pemasok, bahan baku, dan pelanggan 
semuanya itu saling berkaitan. Dalam strategi pemasaran ada faktor-faktor yang harus diperhatikan yang disebut dengan 4P yaitu product (produk), price (harga), place (tempat) dan promotion (promosi). Pada home industry Kue Gapit Sampurna Jaya yang terdapat di Desa Panembahan blok Sampurna ini masih kurang dalam hal promosi. Mereka hanya mengandalkan para pembeli yang sudah menjadi pelanggan dan konsumen sekitar yang cakupannya hanya wilayah Cirebon.

3. Opportunities (Peluang) Oppotunities adalah faktor-faktor eksternal suatu perusahaan yang bersifat menguntungkan bahkan dapat dijadikan senjata untuk memajukan sebuah perusahaan tersebut. Peluang ini tergolong strategi yang sangat ampuh bagi setiap pengusaha untuk mendapatkan keuntungan yang besar, begitu juga dengan Home Industry Kue Gapit Sampurna Jaya ini untuk memanfaatkan peluang yang ada pada home industri gapit tersebut. Karena suatu usaha dapat berkembang dengan memanfaatkan peluang-peluang yang muncul kemudian dimanfaatkan oleh setiap perusahaan. Berikut yang menjadi peluang pada home indusri Kue Gapit Sampurna Jaya adalah :

a. Inovasi pengembangan Inovasi tentu sangat diperlukan dalam mengembangkan suatu produk agar masyarakat tidak merasa bosan terhadap produk yang di jual. Dengan menambah jenis rasa baru dari gapit agar para konsumen semakin tertarik terhadap produk yang ditawarkan.

b. Pemasaran sudah mulai online

Memperluas dunia pemasaran gapit akan sangat berpengaruh terhadap peningkatan kualitas produk serta dapat meningkatkan usaha gapit tersebut. Dengan mencantumkan alamat di google maps "Gapit Sampurna Jaya" .

c. Tingkat harga yang ditawarkan lebih menarik

Harga pada Home Industry gapit Sampurna Jaya dimulai dari ukuran kecil hingga besar yaitu ukuran seperempat, setengah kilo dan satu kilogram. Para konsumen tidak perlu khawatir apabila ingin membeli gapit dalam ukuran kecil maupun besar serta harganya pun terjangkau.

d. Perbedaan rasa dengan gapit lainnya

Home Industry gapit Sampurna Jaya memiliki rasa yang berbeda dengan gapit yang lainnya. Hal ini tentu dapat dijadikan ciri tersendiri untuk menarik para konsumen agar tetap ketagihan. 


\section{e. Kue Gapit adalah Oleh-oleh khas Cirebon}

Oleh-oleh daerah adalah bawaan wajib yang dibeli ketika mengunjungi suatu daerah. Gapit termasuk oleh-oleh khas Cirebon yang biasanya wajib dibawa untuk dijadikan cemilan ringan saat santai. Rasanya yang gurih dan renyah tentu akan dicari oleh masyarakat saat berkunjung ke Cirebon. Home Industry kue gapit Sampurna Jaya sudah memiliki pemasok jenis oleh-oleh khas Cirebon di sekitar daerah Plered dan Bode.

\section{Threats (Ancaman)}

Threats merupakan kebalikan dari opportunities atau peluang. Threats adalah suatu kondisi eksternal yang dapat mengganggu kelancaran berjalannya sebuah perusahaan. Faktor-faktor eksternal yang dapat mempengaruhi strategi perkembangan setiap perusahaan dalam mencapai tujuan perusahaan tersebut. Ancaman sebenarnya tidak bisa dihilangkan dalam suatu usaha namun dapat diatasi dengan cara diminimalisir dengan kekuatan yang dimiliki suatu perusahaan. Berikut yang menjadi ancaman pada Home Industry Kue Gapit Sampurna Jaya diantaranya:

a. Pesaing bisnis yang sejenis

Pesaing merupakan salah satu ancaman dari faktor eksternal suatu perusahaan. Apabila suatu perusahaan mampu bersaing maka pesaing bisa dijadikan alat cambuk untuk lebih meningkatkan usahanya agar lebih berkembang. Di Desa Panembahan banyak pengusaha gapit, tetapi Home Industry gapit Sampurna Jaya lebih menjaga produknya agar tetap baik dan berkualitas.

b. Berkurangnya pembeli karena produk pesaing

Produk pesaing memang sangat banyak dan semakin meningkat, terkadang produk pesaing lebih menarik dan murah harganya dari gapit Sampurna Jaya maka dengan mudah para pembeli beralih produk.

c. Permintaan gapit hanya musiman

Usaha makanan ringan biasanya ramai permintaan konsumen hingga membludak itu saat menjelang bulan puasa hingga lebaran. Seperti yang dialami oleh Home Industry gapit Sampurna Jaya ini, mereka sempat kewalahan menerima pesanan menjelang bulan ramadhan. Kalau hari biasanya gapit Sampurna Jaya bisa dikatakan dapat memproduksi kurang lebih 50 kilogram. Jika menjelang ramadhan produksi gapit bisa mencapai 100 kilogram perharinya. 
d. Rasa bosan terhadap produk

Ada kalanya masyarakat mulai bosan terhadap camilan gapit ini.Tetapi masalah ini bisa diatasi dengan cara menciptakan produk gapit baru yang berbeda dari yang sudah ada. Cara ini dilakukan supaya pelanggan gapit semakin tertarik dan penasaran dengan hal-hal baru.

e. Kenaikan harga bahan baku produksi

Bahan baku produksi yang digunakan untuk membuat gapit seringkali mengalami kenaikan. Solusi yang dilakukan Home Industry gapit Sampurna Jaya apabila mngalami kenaikan pada bahan baku gapit, mereka biasanya dengan menaikkan harga produk gapit nya.

\section{Matriks SWOT}

Matriks SWOT adalah alat yang digunakan untuk menyusun faktor-faktor strategis suatu perusahaan. Matriks SWOT menggambarkan secara jelas bagaimana peluang dan ancaman internal yang dihadapi dapat disesuaikan dengan kekuatan dan kelemahan internal yang dimiliki perusahaan tersebut. Matriks ini dapat menggambrakan kemungkinan empat alternatif strategis yang tepat untuk dilakukan oleh home industry Kue Gapit Sampurna Jaya yang ada di Desa Panembahan Kecamatan Plered Kabupaten Cirebon. Berikut ini adalah matriks SWOT Home Industry Kue Gapit Sampurna Jaya.

Tabel 1. Matriks SWOT Home Industry Kue Gapit Sampurna Jaya

\begin{tabular}{|c|c|c|}
\hline Internal & Kekuatan & Kelemahan \\
\hline $\begin{array}{l}\text { Eksternal } \\
\text { Factor Analysis } \\
\text { (EFAS) }\end{array}$ & $\begin{array}{l}\text { - Produk tahan lama dan } \\
\text { berkualitas } \\
\text { - Bahan baku mudah didapat } \\
\text { - Lokasi usaha yang strategis } \\
\text { - Memiliki sita rasa khas } \\
\text { - Harga yang bersaing dalam } \\
\text { mementingkan produk }\end{array}$ & $\begin{array}{l}\text { - Tidak adanya pelatihan } \\
\text { pada tenaga kerja } \\
\text { - Modal usaha terbatas } \\
\text { - Tidak terdapat lahan parkir } \\
\text { konsumen }\end{array}$ \\
\hline Peluang & SO Strategy & WO Strategy \\
\hline $\begin{array}{l}\text { Inovasi pengembangan } \\
\text { produk } \\
\text { - Pemasaran online }\end{array}$ & $\begin{array}{l}\text { - Meningkatkan mutu produk } \\
\text { untuk menarik pelanggan } \\
\text { baru } \\
\text { - Mempertahankan harga }\end{array}$ & $\begin{array}{l}\text { - Mengadakan pelatihan pada } \\
\text { tenaga kerja untuk } \\
\text { meningkatkan kualitas } \\
\text { produk }\end{array}$ \\
\hline
\end{tabular}




\begin{tabular}{|c|c|c|}
\hline $\begin{array}{l}\text { Tingkat harga yang } \\
\text { ditawarkan lebih } \\
\text { menarik } \\
\text { - Perbedaan rasa dengan } \\
\text { gapit lainnya } \\
\text { - Kue gapit adalah Oleh- } \\
\text { oleh khas Cirebon }\end{array}$ & $\begin{array}{l}\text { - Memaksimalkan produksi } \\
\text { gapit } \\
\text { - Memperluas penawaran } \\
\text { kerjasama penjualan gapit } \\
\text { ke semua toko oleh-oleh di } \\
\text { wilayah Cirebon }\end{array}$ & $\begin{array}{l}\text { - Meningkatkan modal usaha } \\
\text { - Menyediakan lahan parkir } \\
\text { untuk pembeli gapit } \\
\text { - Membuat variasi rasa baru } \\
\text { - Memperluas pemasaran } \\
\text { melalui media sosial }\end{array}$ \\
\hline Tantangan & ST Strategy & WT Strategy \\
\hline $\begin{array}{l}\text { - Persaingan dari produk } \\
\text { daerah lain } \\
\text { - Berkurangnya pembeli } \\
\text { - Parena produk pesaing } \\
\text { hanya musiman } \\
\text { - Rasa bosan terhadap } \\
\text { produk } \\
\text { - Kenaikan harga bahan } \\
\text { baku produksi }\end{array}$ & $\begin{array}{l}\text { - Mempertahankan kualitas } \\
\text { produk } \\
\text { - Meningkatkan daya saing } \\
\text { penjualan } \\
\text { - Menonjolkan keunggulan } \\
\text { produk } \\
\text { - Memiliki cadangan modal } \\
\text { apabila sewaktu- waktu } \\
\text { harga bahan baku naik }\end{array}$ & $\begin{array}{l}\text { - Menjalin hubungan baik } \\
\text { dengan para pelanggan dan } \\
\text { distributor gapit agar tetap } \\
\text { loyal } \\
\text { - Mengamati produk pesaing } \\
\text { bisnis } \\
\text { - Adakan tenaga kerja khusus } \\
\text { untuk pemasaran gapit }\end{array}$ \\
\hline
\end{tabular}

Sumber: Data Primer, 2017

Berdasarkan matriks SWOT diatas dapat menghasilkan empat cara alternatif yang dapat digunakan oleh pemilik Home Industry Kue Gapit Sampurna Jaya dalam menghadapi strategi yang kompetitif, diantaranya ;

\section{Strategi SO (Strength-Opportunities)}

Strategi ini dibuat berdasarkan jalan pikiran perusahaan, ialah dengan menggunakan seluruh kekuatan untuk memanfaatkan peluang. Berikut strategi S-O yang dapat diterapkan diantaranya :

a. Lebih meningkatkan mutu produk untuk menarik pelanggan baru

b. Mempertahankan harga

c. Memaksimalkan produksi gapit

d. Lebih luas menawarkan kerjasama penjualan gapit ke semua toko oleh-oleh di Cirebon 
2. Strategi ST (Strength-Threaths)

Ini adalah strategi untuk kekuatan yang dimiliki perusahaan dengan cara menghindari ancaman atau mengurangi dampak ancaman. Berikut strategi ST yang dapat diterapkan yaitu :

a. Mempertahankan kualitas produk

b. Meningkatkan daya saing penjualan

c. Menonjolkan keunggulan produk

d. Memiliki cadangan modal apabila sewaktu-waktu harga bahan baku naik.

3. Strategi WO (Weakness-Opportunities)

Strategi ini diterapkan berdasarkan pemanfaatan peluang yang dimiliki Home Industry Kue Gapit Sampurna Jaya, dengan cara mengatasi kelemahan-kelemahan yang dimiliki. Berikut strategi WO yang bisa diterapkan ialah :

a. Memberikan pelatihan pada pekerja agar lebih menghasilkan produk yang berkualitas

b. Meningkatkan modal usaha

c. Menyediakan lahan parkir untuk pembeli gapit

d. Membuat variasi rasa baru

e. Memperluas pemasaran di internet

4. Strategi WT (Weakness-Threats)

Strategi ini merupakan taktik untuk bertahan dengan cara mengurangi kelemahan serta menghindari ancaman. Berikut strategi WT yang dapat dilakukan yaitu :

a. Menjalin hubungan baik dengan para pelanggan dan distributor gapit agar tetap loyal

b. Mengamati produk pesaing bisnis

c. Ada tenaga kerja khusus untuk pemasaran gapit

\section{KESIMPULAN DAN SARAN}

Berdasarkan hasil penelitian pada Home Industry Kue Gapit Sampurna Jaya diketahui bahwa terdapat beberapa strategi yang dapat mempengaruhi untuk bersaing dipasaran seperti pada produksi gapit yaitu penggunaan bahan baku yang berkualitas, memprioritaskankan rasa, memaksimalkan produksi untuk memenuhi pesanan konsumen, melakukan pesan antar kepada pelanggan yang memesan dalam jumlah tertentu. Analisis SWOT yang terdiri dari faktor internal (strength, opportunity) dan faktor eksternal (weakness, treatment) yang digunakan pada Home Industry Kue Gapit Sampurna Jaya maka strategi pengembangan usaha yang dapat digunakan Home Industry Kue Gapit Sampurna Jaya berdasarkan matriks SWOT yaitu mempertahankan 
kualitas produk yang berkualitas, menambah modal usaha seperti meminjam pada keluarga atau meminjam uang di bank yang bunganya ringan, membuat variasi rasa baru agar konsumen tidak merasa bosan, ada tenaga kerja khusus dibidang yang memasarkan produk gapit untuk memperluas pangsa pasar dengan cara memasarkannya lewat internet atau media sosial agar produk gapit lebih dikenal seluruh Indonesia.

\section{UCAPAN TERIMA KASIH}

Terimakasih banyak kami ucapkan kepada owner dan seluruh karyawan Home Industry Kue Gapit Sampurna Jaya yang telah berkontribusi mengizinkan sekaligus memberikan informasi yang dibutuhkan penulis dalam menyelesaikan penelitian ini.

\section{DAFTAR PUSTAKA}

Emzir. (2012). Metodologi Penelitian Kualitatif Analisis Data. Jakarta: Raja Grafindo Persada.

Fazizah, A. (2015). Rancangan Business Model Untuk Home Industry “ Kue Pia” Dengan Menerapkan Teori Business Model Canvas. Jurnal Heritage, 3(2), 9-20. Retrieved from https://jurnal.yudharta.ac.id/v2/index.php/HERITAGE/article/view/822

Fitrio, T. (2016). Strategi Pengembangan Home Industri Usaha Kue Rumahan Rumah Bolu ZA Rengat. Jurnal Manajemen Dan Bisnis Indragiri, 29. Retrieved from https://www.researchgate.net/profile/Tomy_Fitrio/publication/336153803_STRATEGI_BI SNIS_RUMAH_BOLU_ZA_RENGAT/links/5d96ff09458515c1d391db89/STRATEGIBISNIS-RUMAH-BOLU-ZA-RENGAT

Hubeis, M. (2009). Prospek Usaha Kecil dalam Wadah Inkubator Bisnis. Bogor: Ghalia Indonesia.

Irmawati. (2015). Analisis Kelayakan Finansial Dan Strategi Pengembangan Usaha Industri Rumahan Gula Semut (Palm Sugar) Dari Nira Nipah Di Kelurahan Pallantikang. Jurnal Pendidikan Teknologi Pertanian, 1(1), 76-94. Retrieved from https://ojs.unm.ac.id/ptp/article/view/5147/2942

Juliandini, A., Syahza, A., \& Indrawati, H. (2017). Development Strategy Of Pastry Business in UMKM Berkah Kota Pekanbaru. Jurnal Online Mahasiswa Fakultas Keguruan Dan Ilmu Pendidikan Universitas Riau, 1-12. Retrieved from https://media.neliti.com/media/publications/201875-strategi-pengembangan-usaha-kue- 


\section{kering-p.pdf}

Mas, V. H., Yantu, M., \& Howara, D. (2013). Prospek Pengembangan Usaha Pada Industri Rumah Tangga Kacang Telur “ Ohara ” Kota Palu. Jurnal Agrotekbis, 1(April), 100-108. Retrieved from http://jurnal.untad.ac.id/jurnal/index.php/Agrotekbis/article/view/1340/958

Muliawan, J. U. (2008). Manajemen Home Industri: Peluang usaha ditengah krisis. Yogyakarta: Banyu Media.

Nazir, M. (2005). Metodologi Penelitian. Jakarta: Ghalia Indonesia.

Nuraini, F. (2019). The Guide of SWOT. Yogyakarta: Quadrant.

Pearce, J., B, R., \& Robinson. (2013). Manajemen Strategis: Formulasi, Implmentasi, dan Pengendalian. Jakarta: Salemba Empat.

Rangkuti, F. (2008). Analisis SWOT Membedah Kasus Bisnis (Tujuh Bela). Jakarta: Gramedia Pustaka Utama.

Riduwan. (2010). Belajar Mudah Penelitian. Bandung: Alfabeta.

Sugiyono. (2005). Memahami Penelitian Kualitatif. Bandung: Alfabeta.

Sulistiowati, Y. T., Aji, J. M. M., \& Hartadi, R. (2017). Analisis Nilai Tambah Dan Tingkat Produktivitas Kerja Serta Strategi Pengembangan Home Industry Gula Kelapa Di Desa Tembokrejo Kecamatan Gubukmas Kabupaten Jember. Jurnal Agribest, 01(02), 110-121. Retrieved from http://jurnal.unmuhjember.ac.id/index.php/AGRIBEST/article/view/1253/1012

Supriadi. (2005). Metodologi Penelitian Ekonomi dan Bisnis. Yogyakarta: UII Press.

Suryabrata, S. (2004). Metodologi Penelitian. Jakarta: Raja Grafindo Persada.

Suryana. (2013). Kewirausahaan. Jakarta: Salemba Empat.

Suryatama, E. (2014). Lebih Memahami Analisis SWOT dalam Bisnis. Surabaya: Kata Pena. Yunus, M. (2008). Islam dan Kewirausahaan Inovatif. Malang: UIN Malang Press.

Zuhri, S. (2013). Analisis Pengembangan Usaha Kecil Home Industri Sangkar Ayam dalam Rangka Pengentasan Kemiskinan. Jurnal Manajemen Dan Akuntansi, 2. Retrieved from http://publishing-widyagama.ac.id/ejournal-v2/index.php/jma/article/view/249/244 
81 | Analisis SWOT Untuk Strategi Pengembangan Home Industry Kue Gapit........... 